\title{
Synergistically increased ILC2 and Th9 cells in lung tissue jointly promote the pathological process of asthma in mice
}

\author{
XINYU YING ${ }^{1}$, ZHAOLIANG SU ${ }^{1}$, QINGLI BIE ${ }^{1}$, PAN ZHANG $^{1}$, HUIJIAN YANG $^{1}$, YUMIN WU ${ }^{1}$, \\ YUNYUN XU ${ }^{1}$, JING WU $^{1}$, MENGYING ZHANG ${ }^{1}$, SHENGJUN WANG ${ }^{1,2}$ and HUAXI XU ${ }^{1}$ \\ ${ }^{1}$ Department of Immunology, School of Medicine, Jiangsu University, Zhenjiang, Jiangsu 212013; \\ ${ }^{2}$ Department of Laboratory Medicine, The Affiliated People's Hospital of Jiangsu University, \\ Zhenjiang, Jiangsu 212001, P.R. China
}

Received May 6, 2015; Accepted March 11, 2016

DOI: $10.3892 / \mathrm{mmr} .2016 .5174$

\begin{abstract}
In recent years, T helper (Th) 9 cells have been demonstrated to be key mediators in immune responses in asthmatic lungs, and innate lymphoid cells 2 (ILC2s) have been described as a novel type of innate immunocyte with the ability to enhance immunoglobulin $\mathrm{E}$ (IgE) production. However, the interaction between ILC2s and Th9 cells in the pulmonary system of a mouse model of asthma remains to be elucidated. In the present study, the response state of lung tissue with regards to Th9 and ILC2s in a mouse model of asthma was investigated by detecting Th9- and ILC2-associated cytokine receptors. The present study also investigated the association between the expression levels of the cytokine receptors in lung tissue samples and the $\operatorname{IgE}$ levels in sera samples from mouse models of asthma. Results from the present study demonstrated that the frequency of ILC2s and Th9 cells was significantly increased in the lung tissue samples, indicating that a Th2-type immune response had occurred. In addition, high mRNA expression levels of RAR-related orphan receptor $\alpha$, interleukin 1 receptor-like 1 , transcription factor PU.1 and interleukin (IL)-9 were observed. Furthermore, IL-5R $\alpha$, IL-13R $\alpha 2$ and high-affinity IgE receptor were increased in mouse models of asthma, and a positive association was observed between the expression levels of ILC2- or Th9-associated receptors in tissue samples and IgE levels in the sera. This indicated that ILC2s and Th9 were in a state of polarization and may promote each other in the lung tissue of mouse models of asthma, and that the lung tissue was responding to the two types of cells via increased expression of receptors.
\end{abstract}

Correspondence to: Professor Huaxi Xu or Professor Shengjun Wang, Department of Immunology, School of Medicine, Jiangsu University, 301 Xuefu Road, Zhenjiang, Jiangsu 212013, P.R. China E-mail: xuhx@ujs.edu.cn

E-mail: sjwjs@ujs.edu.cn

Key words: ILC2s, Th9 cells, cytokines, receptors, asthma

\section{Introduction}

Asthma is one of the most common lifelong chronic diseases, it is a reversible airway obstruction that is characterized by constriction of smooth muscle of the airway, hypersecretion of mucus, edema and airway hyperresponsiveness (AHR), and thickening of the basement membrane of the airway epithelium. During airway inflammation, complex interactions of innate and adaptive immune cells, structural cells and cytokines, exert numerous key effects. Following allergen exposure, airway inflammation is predominantly the result of allergen specific T helper (Th) 2 and other T cells, which recruit and accumulate in the lungs and produce a range of different effector cytokines (1). Th2 cells are important as they produce a number of key cytokines, including interleukin (IL)-4, IL-5 and IL-13, which have been demonstrated to contribute to numerous pathophysiological features of asthma (2). However, the identification of further subtypes of helper $\mathrm{T}$ cells and their cytokines has resulted in reconsideration of the immunopathology of asthma (3).

Th9 cells were first identified as a Th2 subpopulation that produced large quantities of IL-9. However, experimental analyses demonstrated that Th9 cells have divergent regulatory capabilities and are involved in different immune processes $(4,5)$. As the predominant product of Th9 cells, IL-9 is a pleiotropic cytokine that has multiple effects on numerous hematopoietic cells, which are central to the pathogenesis of asthma. IL-9 stimulates the proliferation of activated T cells, promotes the proliferation and differentiation of mast cells and increases production of immunoglobulin (Ig)E by B cells (6). It also promotes expression of mast cell proteases, upregulates the high-affinity $\operatorname{IgE}$ receptor $\left(\mathrm{Fc}_{\varepsilon} \mathrm{R}\right)$ and induces IL-6 production $(7,8)$. Evidence from human and murine studies has suggested that IL-9 is associated with susceptibility to develop $\operatorname{AHR}(9,10)$.

Innate lymphoid cells (ILCs) are important in innate immunity and tissue remodeling via production of various cytokines and growth factors. The ILCs include ILC1 (interferon- $\gamma$-expressing natural killer cells), ILC2 (IL-5 and IL-13-expressing nuocytes) and RAR-related orphan receptor (ROR) $\gamma$ ILCs (IL-17 and IL-22-expressing 'ILC3'). Group 2 ILCs (ILC2s) have recently been demonstrated to mediate the 
Table I. Primer sequences for reverse transcription-polymerase chain reaction.

\begin{tabular}{|c|c|c|}
\hline Gene & Sequence $\left(5^{\prime}-3^{\prime}\right)$ & Length (bp) \\
\hline $\mathrm{ROR} \alpha$ & $\begin{array}{l}\text { F: CTCGTGGCTTCAGGAAAAGGTA } \\
\text { R: TCGTCCACATAGGGCTCTTAAC }\end{array}$ & 151 \\
\hline IL-9 & $\begin{array}{l}\text { F: CACAAATGCACCTTCTGGGACA } \\
\text { R: TCACTCCAACGATACGGTCCTT }\end{array}$ & 119 \\
\hline IL-5 & $\begin{array}{l}\text { F: AGGATGCTTCTGCACTTGAG } \\
\text { R: CCTCATCGTCTCATTGCTTG }\end{array}$ & 144 \\
\hline IL-13 & $\begin{array}{l}\text { F: TGAGCAACATCACACAAGACC } \\
\text { R: AGGCCATGCAATATCCTCTG }\end{array}$ & 157 \\
\hline PU.1 & $\begin{array}{l}\text { F: CCCTCCATCGGATGACTTGGTT } \\
\text { R: GTTGTTGTGGACATGGTGTGCG }\end{array}$ & 142 \\
\hline IL-13R $\alpha 2$ & $\begin{array}{l}\text { F: GGACTCATCAGACTATAAAGATT } \\
\text { R: GTGTGCTCCATTTCATTCTA }\end{array}$ & 176 \\
\hline IL-5R $\alpha$ & $\begin{array}{l}\text { F: CCTATACTACAGGTTTGGTGT } \\
\text { R: GCTTGCTTGAGCCATTAATGT }\end{array}$ & 152 \\
\hline IRF4 & $\begin{array}{l}\text { F: GGTGTGGGAGAACGAGGAGAAG } \\
\text { R: TCCTCTCGACCAATTCCTCAAA }\end{array}$ & 221 \\
\hline MBP-1 & $\begin{array}{l}\text { F: TCTGACTCCAAAAGCCCATT } \\
\text { R: AAGGTCCACGTCTGTCACAT }\end{array}$ & 195 \\
\hline $\mathrm{Fc}_{\varepsilon} \mathrm{R} 1 \alpha$ & $\begin{array}{l}\text { F: GAACTCTTCACATTTGGTCA } \\
\text { R: GCGTTACATTCAAGTACACA }\end{array}$ & 110 \\
\hline$\beta$-actin & $\begin{array}{l}\text { F: TGGAATCCTGTGGCATTCATGAAAC } \\
\text { R: TAAAACGCAGCTCAGTAACAGTCCG }\end{array}$ & 349 \\
\hline
\end{tabular}

F, forward; R, reverse; ROR $\alpha$, RAR-related orphan receptor $\alpha$; IL, interleukin; PU.1, transcription factor PU.1; IRF4, interferon regulatory factor 4; MBP-1, c-myc binding protein $1 ; \mathrm{Fc}_{\varepsilon} \mathrm{R}_{\mathrm{Ia}}$, high-affinity $\operatorname{IgE}$ receptor $1 \alpha$.

immune pathology of asthma even without adaptive immunity, and are found in human respiratory and gastrointestinal tissues, as well as in skin (11-14). The present study described the response state of lung tissue to Th9 cells and ILC2s in mouse models of asthma by detecting associated receptors, and analyzing the association between the receptors and $\operatorname{IgE}$ levels in sera samples from the mice.

\section{Materials and methods}

Animals and asthma induction. Female BALB/c mice (age, 6 weeks; weight, $18 \pm 2 \mathrm{~g}$ ) were purchased from the Laboratory Animal Center of Yangzhou University (Yangzhou, China). Mice were housed in plastic cages with sterilized wood-chip bedding, and bred in animal rooms maintained at a temperature of $23 \pm 2^{\circ} \mathrm{C}$ and a relative humidity of $55 \pm 10 \%$ with a $12 \mathrm{~h}$ light-dark cycle. They had access to tap water and normal diet ad libitum. The mouse model of allergic airway inflammation was established, as described by Wang et al (15) with slight modification. Briefly, the mice were sensitized by intraperitoneal (i.p.) injection of $50 \mu \mathrm{g}$ ovalbumin (OVA; Sigma-Aldrich, St. Louis, MO, USA) protein and $2 \mathrm{mg}$ aluminum hydroxide gel (Sigma-Aldrich) in saline (Sinopharm Group Co., Ltd., Shanghai, China). A second sensitization was given 10 days after the initial sensitization. On day 22 after initial sensitization, mice were placed in a Plexiglas chamber linked to an ultrasonic nebulizer (NE-C29; Dalian Medical Ultrasonic Instrument Co., Ltd., Dalian, China) and challenged with aerosolized OVA solution (10 $\mathrm{mg} / \mathrm{ml}$ in saline) for $60 \mathrm{~min}$. The provocation was performed once a day for 5 consecutive days and then the mice were assessed for allergic inflammation of the lungs $24 \mathrm{~h}$ after the final aerosol exposure. Subsequent to this, the mice were anesthetized with ketamine $(100 \mathrm{mg} / \mathrm{kg}$ i.p.) and the left lung was obtained by aseptic surgery, from which the tissue samples were randomly selected. The present study was approved by the Ethical Committee of Jiangsu University (Zhenjiang, China).

Hematoxylin and eosin $(H \& E)$ and immunofluorescence staining. Lung tissue samples from mouse models of asthma were obtained and fixed in $4 \%$ paraformaldehyde (Sinopharm Group Co., Ltd.) and embedded in paraffin (Sinopharm Group Co., Ltd.). The blocks were cut into $4-\mu \mathrm{m}$ sections, heated for $3 \mathrm{~h}$ in a $37^{\circ} \mathrm{C}$ incubator, and then dewaxed and stained with H\&E (BaSo Diagnostics Inc., Zhuhai, China). One section was selected from each mouse and observed under a microscope (CX21BIM-SET5; Olympus Corporation, Tokyo, Japan).

Immunofluorescence staining. Immunofluorescence staining was performed on paraffin-embedded mouse lung tissue as described previously (16). Briefly, following dewaxing and antigen retrieval (in 1\% sodium citrate solution for $10 \mathrm{~min}$ at $90-95^{\circ} \mathrm{C}$.), the slides were blocked in $1 \%$ (weight/volume) bovine serum albumin (Sigma-Aldrich) for $60 \mathrm{~min}$ at $37^{\circ} \mathrm{C}$, and then the slides were incubated with primary antibodies for $2 \mathrm{~h}$ at room temperature, as follows: Polyclonal goat 
A

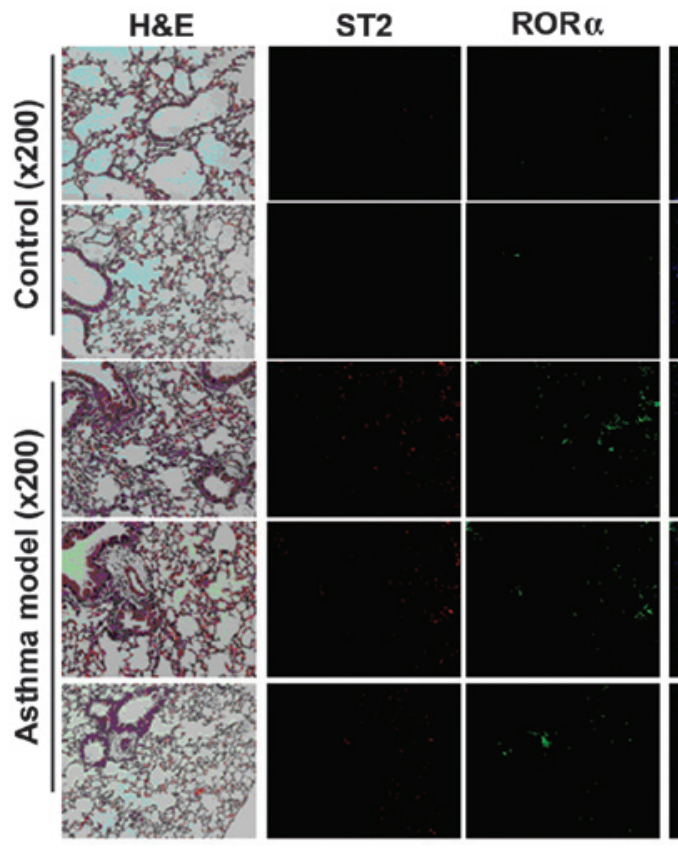

Merge

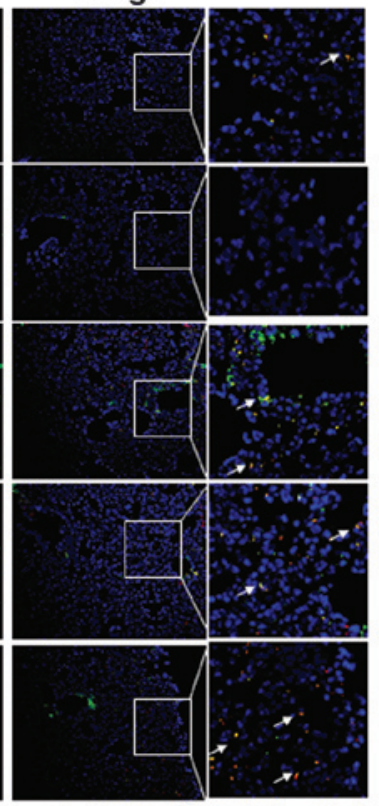

B

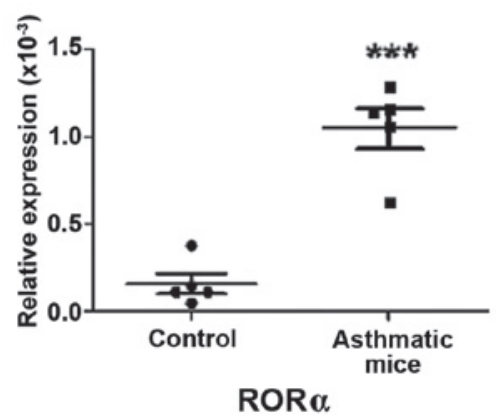

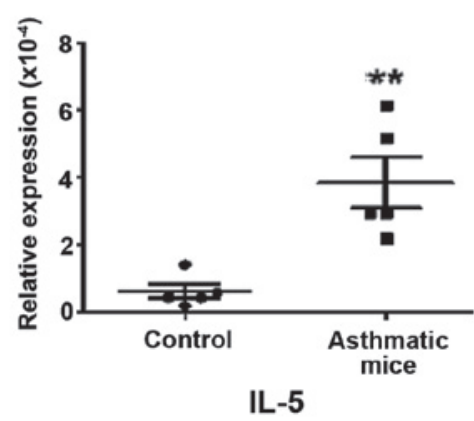

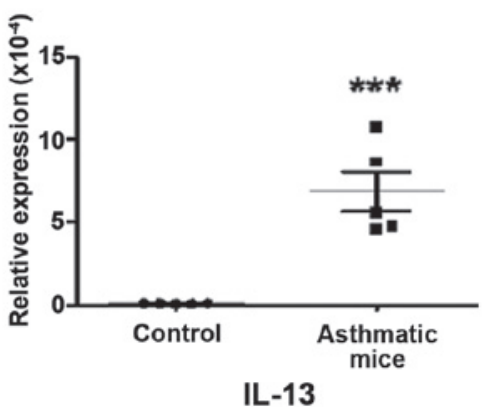

Figure 1. Expression of ILC2-associated cytokines, transcription factors, and membrane molecules in lung tissue samples from asthmatic mice. (A) Histopathological and immunofluorescence staining results demonstrated that, compared with the control group, the expression of ST2 and ROR $\alpha$ were significantly increased in lung tissue samples from asthmatic mice. (B) The results of the reverse transcription-quantitative polymerase chain reaction showed that the mRNA expression levels of ILC2-associated transcription factors and cytokines in lung tissue in asthmatic mice were markedly increased compared with the control group ${ }^{* *} \mathrm{P}<0.001 ;{ }^{* * *} \mathrm{P}<0.0001$ vs. the control group. H\&E, hematoxylin and eosin; ST2, interleukin 1 receptor-like 1 ; ROR $\alpha$, RAR-related orphan receptor $\alpha$; IL, interleukin; ILC2, innate lymphoid cell 2.

anti-mouse IL-9 (cat. no. sc-1272; Santa Cruz Biotechnology, Inc., Dallas, TX, USA; dilution, 1:100), rabbit anti-mouse cluster of differentiation (CD)3 (cat. no. ab16669; Abcam, Cambridge, UK; dilution, 1:100), polyclonal rat anti-mouse CD117 (c-kit)-PE (cat. no. 135105; BioLegend, Inc., San Diego, CA, USA; dilution, 1:100), polyclonal Armenian hamster anti-mice $\mathrm{Fc}_{\varepsilon} \mathrm{RI} \alpha$-FITC (cat. no. 134305; BioLegend, Inc.; dilution, 1:100), polyclonal rabbit anti-mouse ROR $\alpha$ (cat. no. ab60134; Abcam, Cambridge, UK; dilution, 1:100) and polyclonal goat anti-mouse ST2 (cat. no. sc-18687; Biotechnology, Inc.; dilution, 1:100). Subsequent to washing, the labeled secondary antibodies were incubated with the slides for $90 \mathrm{~min}$ at $37^{\circ} \mathrm{C}$, as follows: Polyclonal donkey anti-goat PE (cat. no. sc-3743; Santa Cruz Biotechnology, Inc.; dilution, 1:200) and polyclonal donkey anti-rabbit FITC (cat. no. sc-2090; Santa Cruz Biotechnology, Inc.; dilution, 1:200). Finally, the slides were dyed in Hoechst 33342 (Beyotime Institute of Biotechnology, Shanghai, China) for $10 \mathrm{~min}$. All the sections were coverslipped with Vectashield mounting medium (Vector Laboratories, Inc., Burlingame,
CA, USA), viewed with a fluorescence microscope (Olympus Corporation, Tokyo, Japan), and analyzed using ImageJ software (imagej.nih.gov/ij/).

$R N A$ extraction and reverse transcription-quantitative polymerase chain reaction ( $R T-q P C R)$. Total RNA was extracted using Invitrogen TRIzol (Thermo Fisher Scientific, Inc., Waltham, MA, USA) and 500 ng RNA was reverse transcribed using PrimeScript ${ }^{\circledR}$ RT reagent kit (Takara Bio, Inc., Otsu, Japan), according to the manufacturer's protocols at $37^{\circ} \mathrm{C}$ for $15 \mathrm{~min}$ and $85^{\circ} \mathrm{C}$ for $5 \mathrm{sec}$. On the basis of Genebank sequences (www.ncbi.nlm.nih.gov/genbank), the primers used in the present study were designed by Primer Premier 5.0 software (http://www.premierbiosoft.com/primerdesign/index.html) and synthesized by Invitrogen (Thermo Fisher Scientific, Inc.). The sequences of the primers are presented in Table I. qPCR was conducted using a CFX96 Real-Time PCR Detection system (Bio-Rad Laboratories, Inc., Hercules, CA, USA) and SYBR $^{\circledR}$ Premix Ex Taq ${ }^{\mathrm{TM}}$ (Takara Bio, Inc.) according to the manufacturer's protocols. Fold changes in the expression 
A
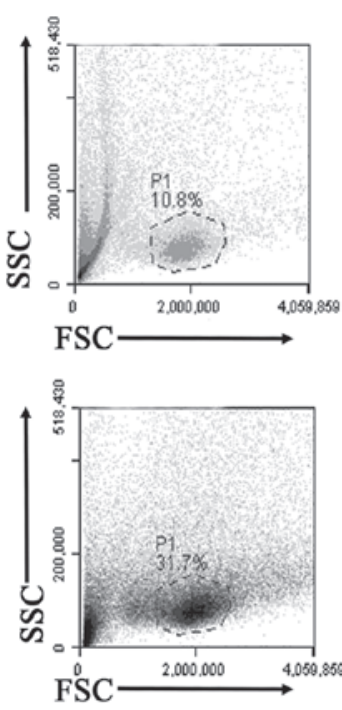

B
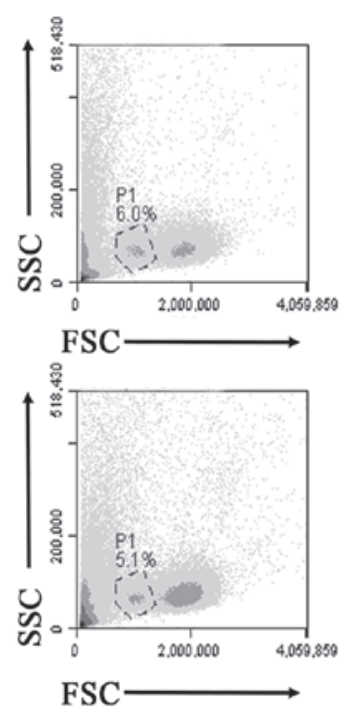
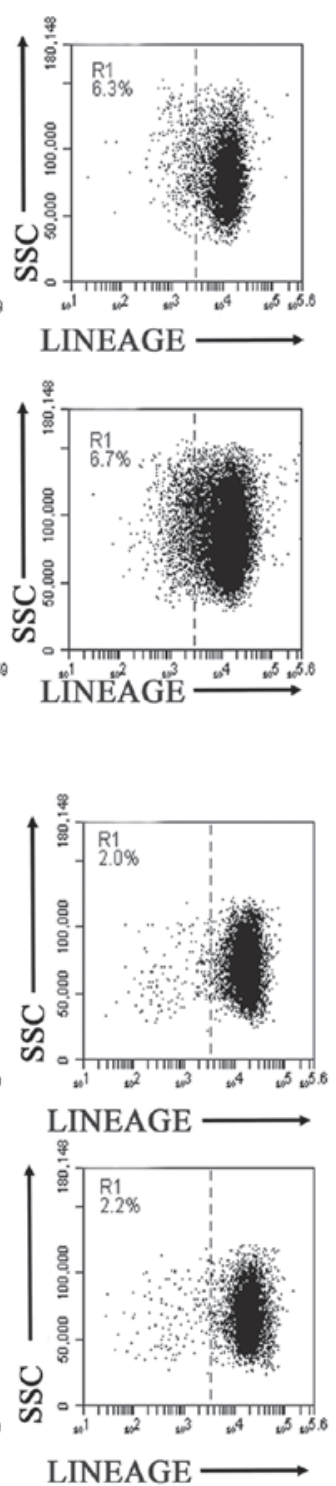
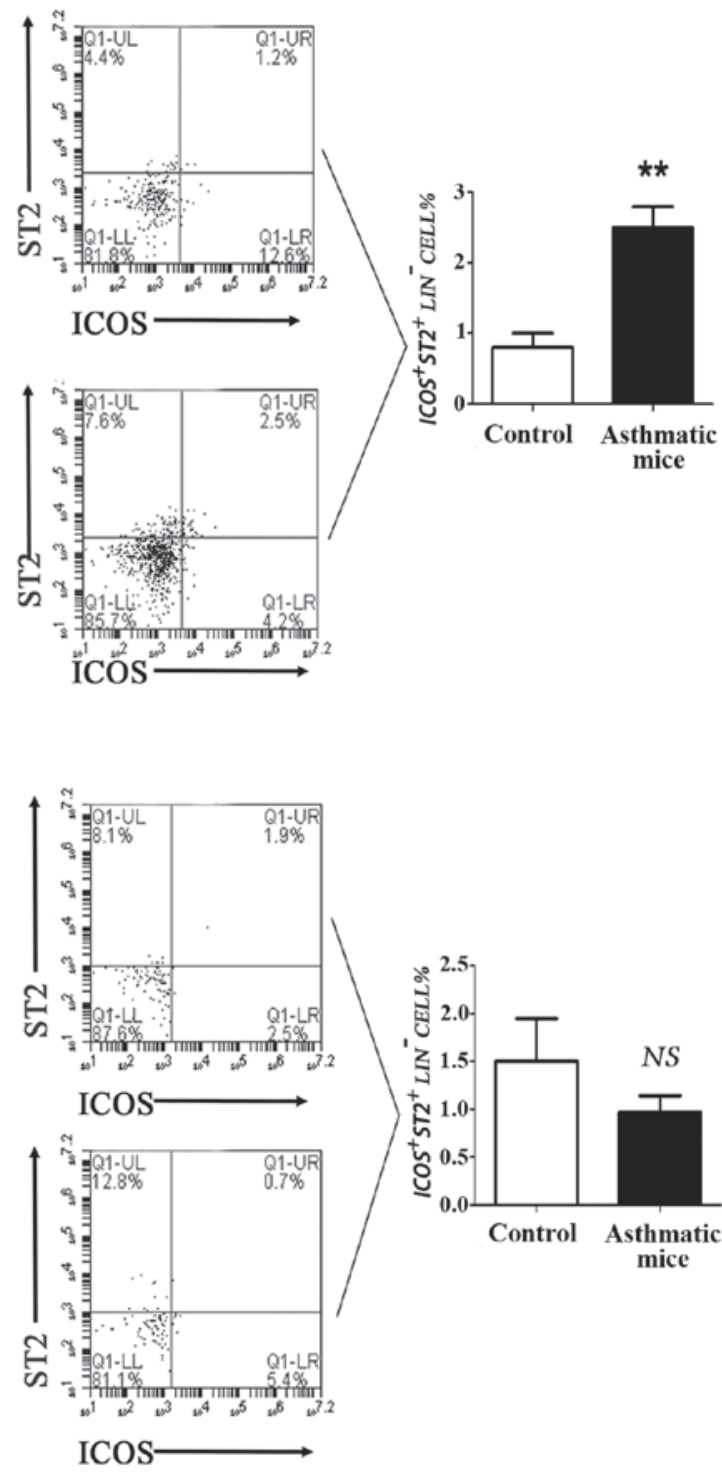

Figure 2. Frequency of ILC2s was significantly increased in the lung tissue samples from asthmatic mice, but not in peripheral blood samples. (A) Flow cytometric analysis showed that the number of ILC2s in lung tissue samples from asthmatic mice was higher than that of the control group $\left(^{* *} \mathrm{P}<0.01\right.$ vs. the control group). (B) The result of flow cytometric analysis indicated that the number of ILC2s in peripheral blood samples from asthmatic mice was not significantly different, compared with the control mice ( $\mathrm{P}=0.3325 \mathrm{vs}$. the control group). FSC corresponds to the relative size of the cell, the greater the value of FSC, the larger the cell; SSC corresponds to the degree of internal complexity of the cell, the greater the value of SSC, the greater the number of particles inside the cell. LIN, cell lineage; ILC2s, innate lymphoid cells 2; ICOS, inducible T-cell costimulator; NS, not significant; ST2, interleukin 1 receptor-like 1.

of each objective gene relative to $\beta$-actin were calculated based on the quantification cycle $(\mathrm{Cq})(17)$. All samples were performed in triplicate.

Flow cytometric quantification of ILC2s and Th9. The ILC2s or Th9 population was defined as $\mathrm{CD} 278^{+} \mathrm{ST} 2^{+}$lineage (LIN)- or IL-9 ${ }^{+} \mathrm{IL}_{-} 4^{-}$. Lung tissue samples or PBMCs were freshly obtained from mouse models of asthma. A lung tissue single cell suspension was isolated by sieving, and peripheral blood mononuclear cells (PBMCs) were obtained by standard Ficoll-Hypaque density centrifugation (Tian Jin Hao Yang Biological Manufacture Co., Ltd., Tianjin, China). Subsequently, the cells were cultured at $37^{\circ} \mathrm{C}$ in an atmosphere of $5 \% \mathrm{CO}_{2}$ for $5 \mathrm{~h}$, and incubated with antibodies, as follows: Polyclonal rat anti-mouse ST2-PE (cat. no. 145303; BioLegend, Inc.; dilution, 1:200), polyclonal Syrian hamster anti-mouse-CD278 (inducible T-cell costimulator)-PerCP/Cy5.5 (cat. no. 107705; BioLegend, Inc.; dilution, 1:200), polyclonal mouse anti-mouse hematopoietic LIN-FITC (cat. no. 22-7770-72; eBioscience, Inc., San Diego, CA, USA; dilution, 1:200) for the ILC2 cells; polyclonal rat anti-mouse IL-9-PE (cat. no. 514103; BioLegend, Inc.; dilution, 1:200), polyclonal rat anti-mouse IL-4-PerCP/Cy5.5 (cat. no. 504123; BioLegend, Inc.; dilution, 1:200) for the Th9 cells. The following isotype control antibodies were used in all the investigations: Polyclonal rat immunoglobulin (Ig) G-PE (cat. no. B157311; Biolegend, Inc.; dilution, 1:200) and polyclonal rat IgG-PerCP/ Cy5.5 (cat. no. 400425; Biolegend, Inc.; dilution, 1:200). For intracellular cytokine measurement, the single cell suspension was treated with cell lysis buffer (Hanks' Balanced Salt Solution; eBioscience, Inc., San Diego, CA, USA) for $10 \mathrm{~min}$ 
A
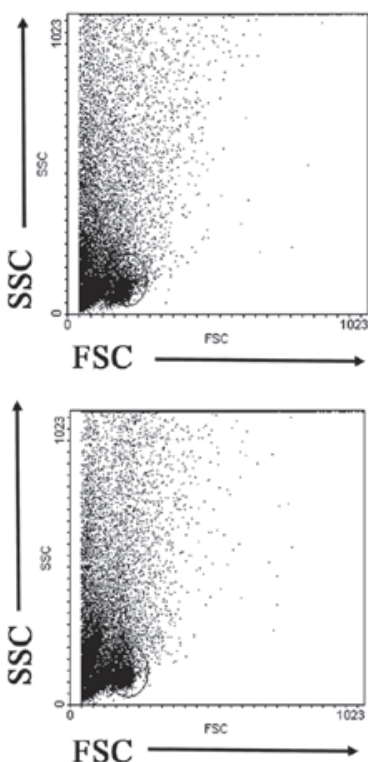

C
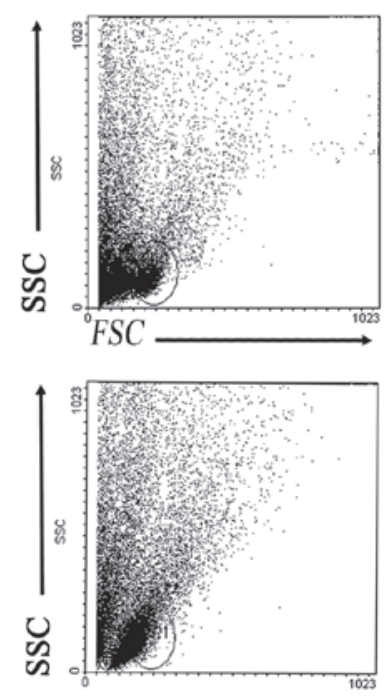

FSC
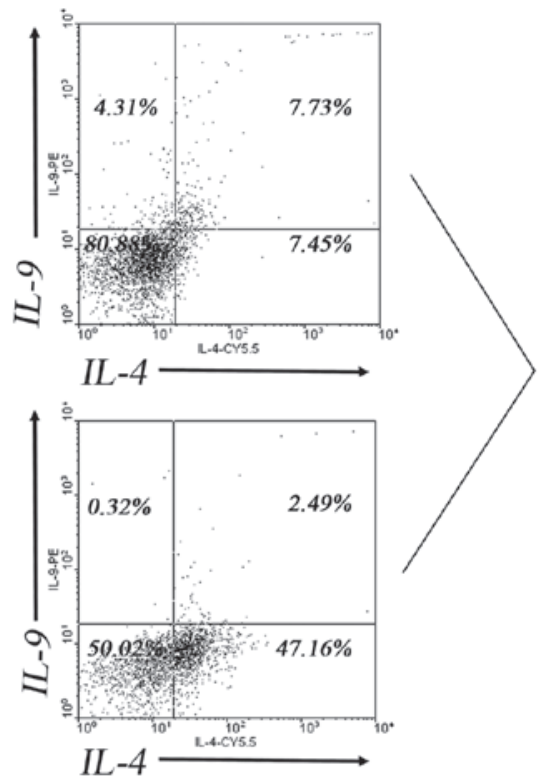

B
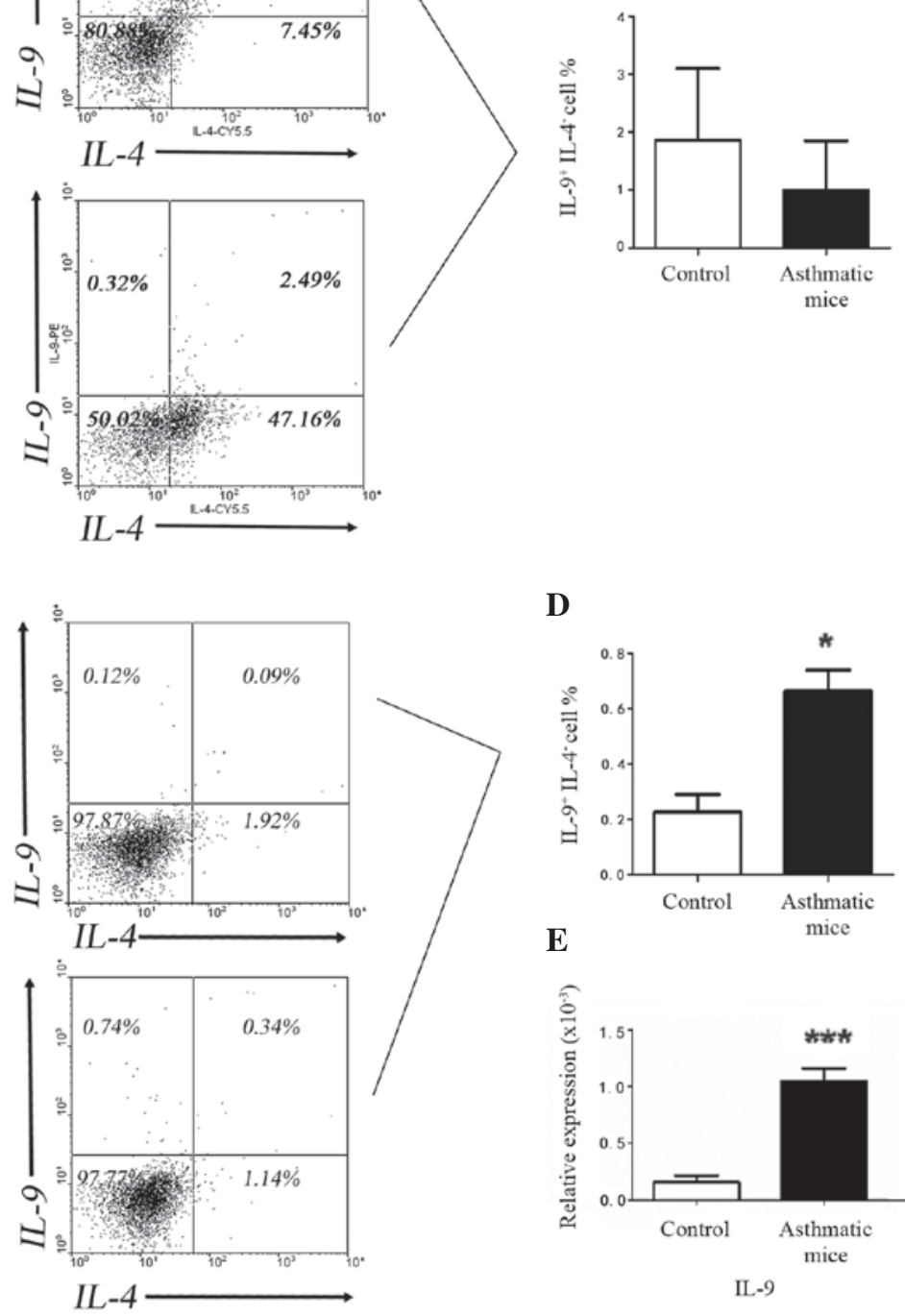

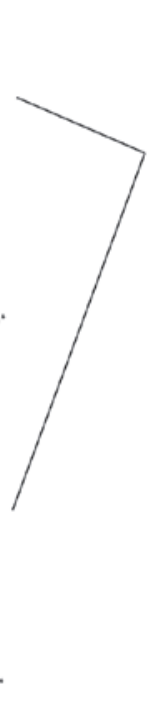

D

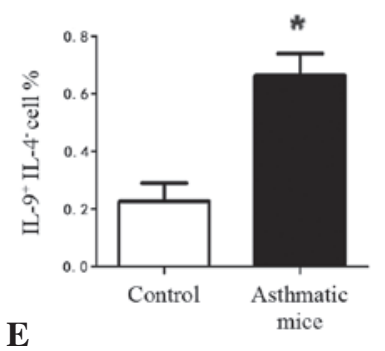

E

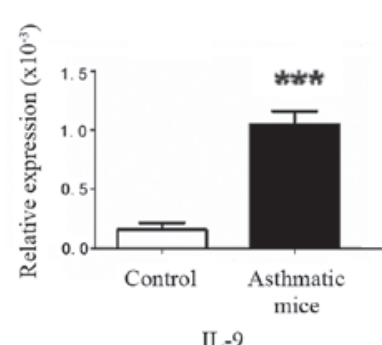

Figure 3. Frequency of Th9 cells in peripheral blood and lung tissue. The result of flow cytometric analysis for Th9 cells in peripheral blood demonstrated there was no significant difference between (A) asthmatic mice and (B) control mice. However, the result of flow cytometric analysis for Th9 cells in lung tissue demonstrated that the frequency of Th9 cells from (C) asthmatic mice was markedly higher than that in the (D) control group. The reverse transcription-quantitative polymerase chain reaction result showed that the mRNA expression levels of IL-9 were significantly increased in lung tissue samples from (E) asthmatic mice. ${ }^{* *} \mathrm{P}<0.05,{ }^{* * *} \mathrm{P}<0.0001$ vs. the control. FSC corresponds to the relative size of the cell, the greater the value of FSC, the larger the cell; SSC corresponds to the degree of internal complexity of the cell, the greater the value of SSC, the greater the number of particles inside the cell. Th9; T helper 9; IL, interleukin.

prior to flow cytometric analysis using a BD FACSCalibur ${ }^{\mathrm{TM}}$ (BD Biosciences, Franklin Lakes, NJ, USA). Cells were then analyzed using FlowJo software version 10.0.7 (http://www. flowjo.com/download-flowjo/).

Enzyme-linked immunosorbent assay (ELISA) for serum IgE. The serum IgE was measured by ELISA kit according to the manufacturer's protocols (eBioscience, Inc.). All samples were measured in triplicate, and the mean concentration was calculated from a standard curve.

Statistical analysis. All statistical analysis was performed using SPSS software version 16.0 (SPSS, Inc., Chicago, IL, USA) and data were expressed as the mean \pm standard deviation. Comparisons between groups were performed using the unpaired Student's t-test and Pearson's correlation was used to test correlation between two continuous variables. $\mathrm{P}<0.05$ was considered to indicate a statistically significant difference.

\section{Results}

Increased ILC2s frequency and their associated factors in lung tissue samples from mouse models of asthma. The transcription factor ROR $\alpha$ is essential for the development and function of ILC2s. ST2 is relatively specific receptor or surface marker expressed by ILC2s and IL-5 and IL-13 are characteristic cytokines. To analyze the level of ILC2s in lung 


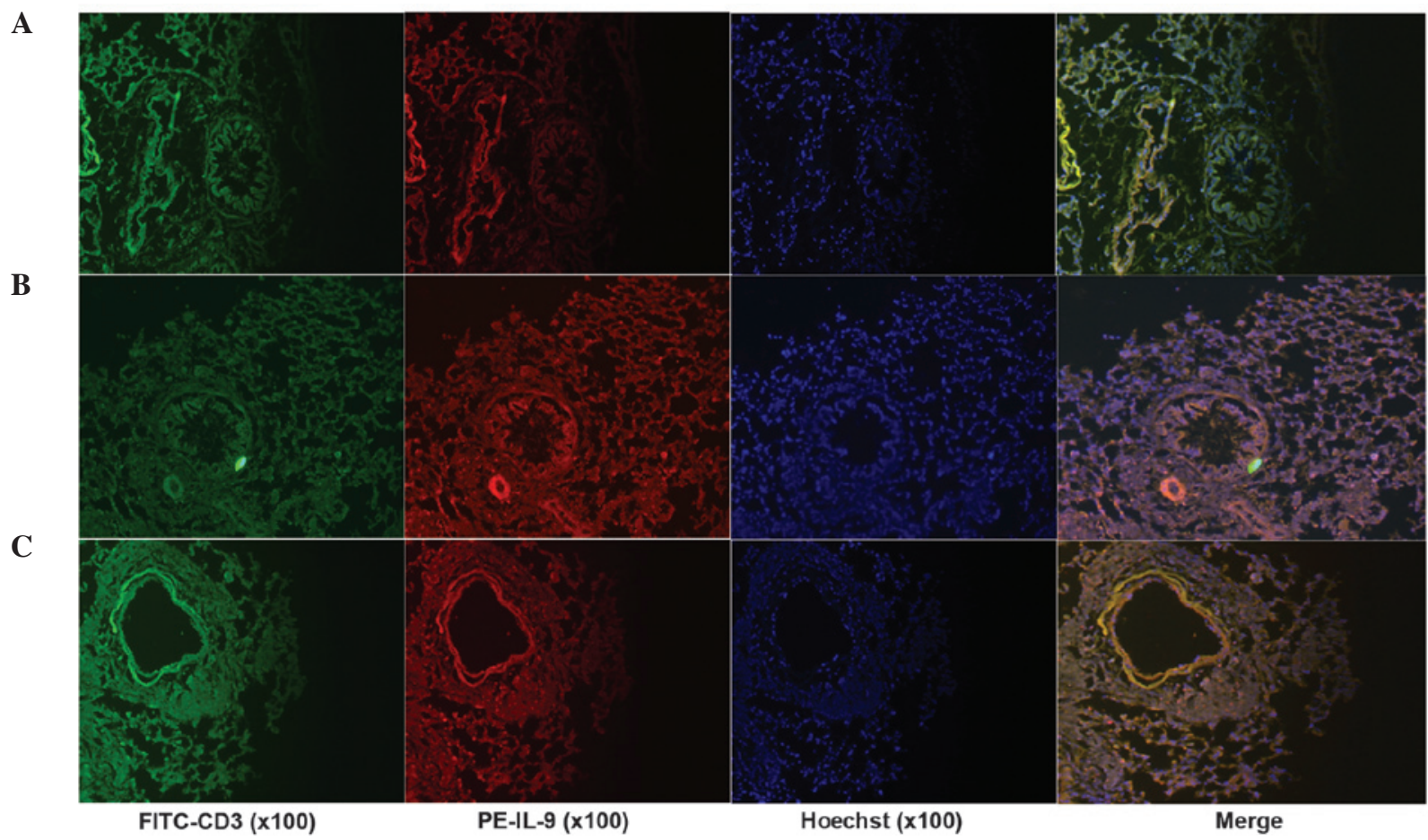

Figure 4. Th9 cells were observed in the inflammatory lung tissue by immunofluorescence staining. FITC-CD3 and FE-IL-9 antibodies were used to detect the Th9 cells in inflammatory lung tissue by immunofluorescence staining, and the results were observed by fluorescence microscopy. (A) In lung tissue samples from control mice, positive staining was rarely observed. (B and C) In samples from asthmatic mice, the positive staining was markedly increased compared with the control. FITC, fluorescein isothiocyanate; CD, cluster of differentiation; PE, phycoerythrin; IL, interleukin.

tissue samples from mouse models of asthma, the ROR $\alpha$, ST2, IL-5 and IL-13 were detected by immunofluorescence staining or RT-qPCR. As presented in Fig. 1, the mRNA expression levels of ROR $\alpha$, IL-5 and IL-13 were significantly increased in asthmatic mice $(\mathrm{P}=0.0001, \mathrm{P}=0.0003$ and $\mathrm{P}=0.0005$, respectively), and the results of immunofluorescence staining indicated ST2 and ROR $\alpha$ positive cells in lung tissue samples of asthmatic mice. In addition, the results of flow cytometry analysis demonstrated that the percentage of ILC2s was increased in the lung tissue samples of asthma mouse models, but no marked changes were observed in PBMCs (Fig. 2).

These results suggested that ILC2s and their characteristic transcription factors or cytokines were notably upregulated in lung tissue samples in asthmatic mice.

Increased Th9 and ILC2s frequency in lung tissue samples from mouse models of asthma. A number of groups have reported that IL-9 production is increased in the lungs of human patients with chronic asthma $(18,19)$. However, although Th9 cells have recently been identified in vitro $(20,21)$, it remains to be elucidated whether these are the predominant cellular sources of IL-9 during chronic allergic inflammation. Mouse models of asthma were used to investigate the development of IL-9 and other key cytokines by effector T cells. The results of flow cytometric analysis and RT-qPCR (Fig. 3) demonstrated a decreased percentage of IL-9+ IL-4 $^{-}$cells $(\mathrm{P}>0.05)$ in the peripheral blood from the asthmatic mouse samples compared with the control mice (Fig. 3B) . However, Fig.3C and $\mathrm{D}$ demonstrate that the percentage of IL-9+ $\mathrm{IL}-4^{-}$cells and expression levels of IL-9 mRNA were significantly increased
$(\mathrm{P}<0.05$ and $\mathrm{P}<0.0001$, respectively) in lung tissue samples from the asthmatic mice when compared with the control mice. Results from the present study indicate that Th9 cells may be important in the local inflammation of lung tissue. Immunofluorescence staining also indicated that IL- $9^{+}$cells were observed in inflammatory lung tissue (Fig. 4). Results from the present study suggested that Th9 cells may be important in the local inflammation of lung tissue.

PU.1 is reported to be an important transcriptional regulator of Th9 cell differentiation. In addition, a number of studies have indicated that other factors, including IFN regulatory factor 4 (IRF-4), NF- $\mathrm{BB}$ and c-Myc binding protein 1 (MBP-1) regulate IL-9 production in Th9 cells $(22,23)$. In the present study, increased mRNA expression levels were also observed for PU.1, IRF-4 and MBP-1 were increased (Fig. 5).

IgE in serum and $F c_{\varepsilon} R$ in lung tissue were increased in mouse models of asthma. Elevated serum IgE levels is the predominant pathological manifestation of asthma inflammation. Thus, ELISA was conducted in the present study to investigate the total $\operatorname{IgE}$ content in serum samples from asthmatic mice. The result demonstrated that the level of total $\mathrm{IgE}$ was significantly increased in peripheral blood (Fig. 5). In addition, the immunofluorescence staining indicated that the number of $\mathrm{Fc}_{\varepsilon} \mathrm{R}$ positive cells in inflammatory lung tissue samples was also increased (Fig. 6).

Expression levels of cytokines associated with IgE upregulation were increased. Elevated serum levels of total IgE are associated with atopic diseases, including allergic rhinitis and allergic asthma. IRF4 is a key regulator of numerous 

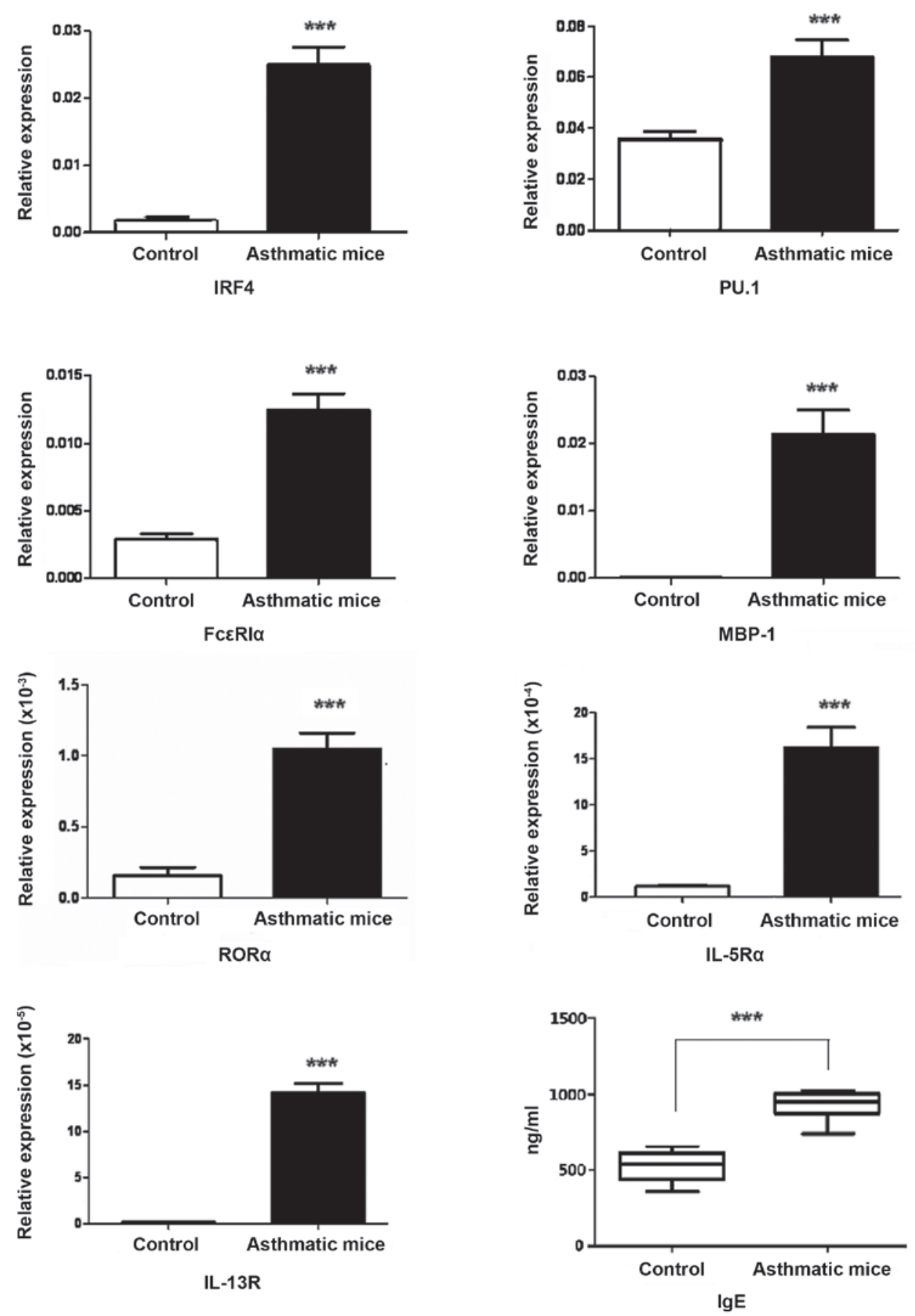

Figure 5. Increased levels of ILC2- and Th9 cell-associated molecules or receptors in inflammatory lung tissue. The expression levels of ILC2- and Th9 cell-associated molecules or receptors in the inflammatory lung tissue were detected by RT-qPCR, all the molecules and receptors were significantly increased. The values indicating the relative expression (fold changes in the expression of each objective gene relative to $\beta$-actin), which were calculated based on the quantification cycle. All analysis of samples was performed in triplicate. RT-qPCR was also conducted to detect $\mathrm{Fc}_{\mathrm{\varepsilon}} \mathrm{RI} \alpha$ in the lung tissue of asthma and enzyme-linked immunosorbent assay was performed to detect serum IgE, the two parameters were observed to be increased. ${ }^{* * *} \mathrm{P}<0.0001 \mathrm{vs}$. the control. ILC2, innate lymphoid cells 2; Th9, T helper 9; RT-qPCR, reverse transcription-polymerase chain reaction; IRF4, interferon regulatory factor 4; PU.1, transcription factor PU.1; IgE, immunoglobulin E; $\mathrm{Fc}_{\varepsilon} \mathrm{RI} \alpha$, high-affinity IgE receptor $1 \alpha$; MBP-1, c-myc binding protein 1; ROR $\alpha$, RAR-related orphan receptor $\alpha$; IL-5R $\alpha$, interleukin 5 receptor $\alpha$; IL-13, interleukin 13 receptor.

steps in lymphoid, myeloid, and dendritic-cell differentiation, including the differentiation of mature $\mathrm{B}$ cells into antibody-secreting plasma cells that produce $\mathrm{IgE}$ and $\mathrm{IgG}$ antibodies, among others. The results from the present study demonstrate that the mRNA expression levels of $\mathrm{Fc}_{\varepsilon} \mathrm{R}$, IRF4 and MBP1 in the inflammatory lung tissue were increased, similarly to the increased serum IgE level (Figs. 5 and 6).
Furthermore, in the inflammatory lung tissue samples, the expression levels of Th9- and ILC2-associated transcription factors, including PU.1 and ROR $\alpha$, or cytokine receptors, including IL-5 receptor $(\mathrm{R})_{\alpha}$ and IL-13R $\mathrm{R}_{\alpha 2}$, were significantly increased $(\mathrm{P}<0.0001)$; indicating that the lung tissue of asthmatic mice exhibited a positive response to the two types of cell. 

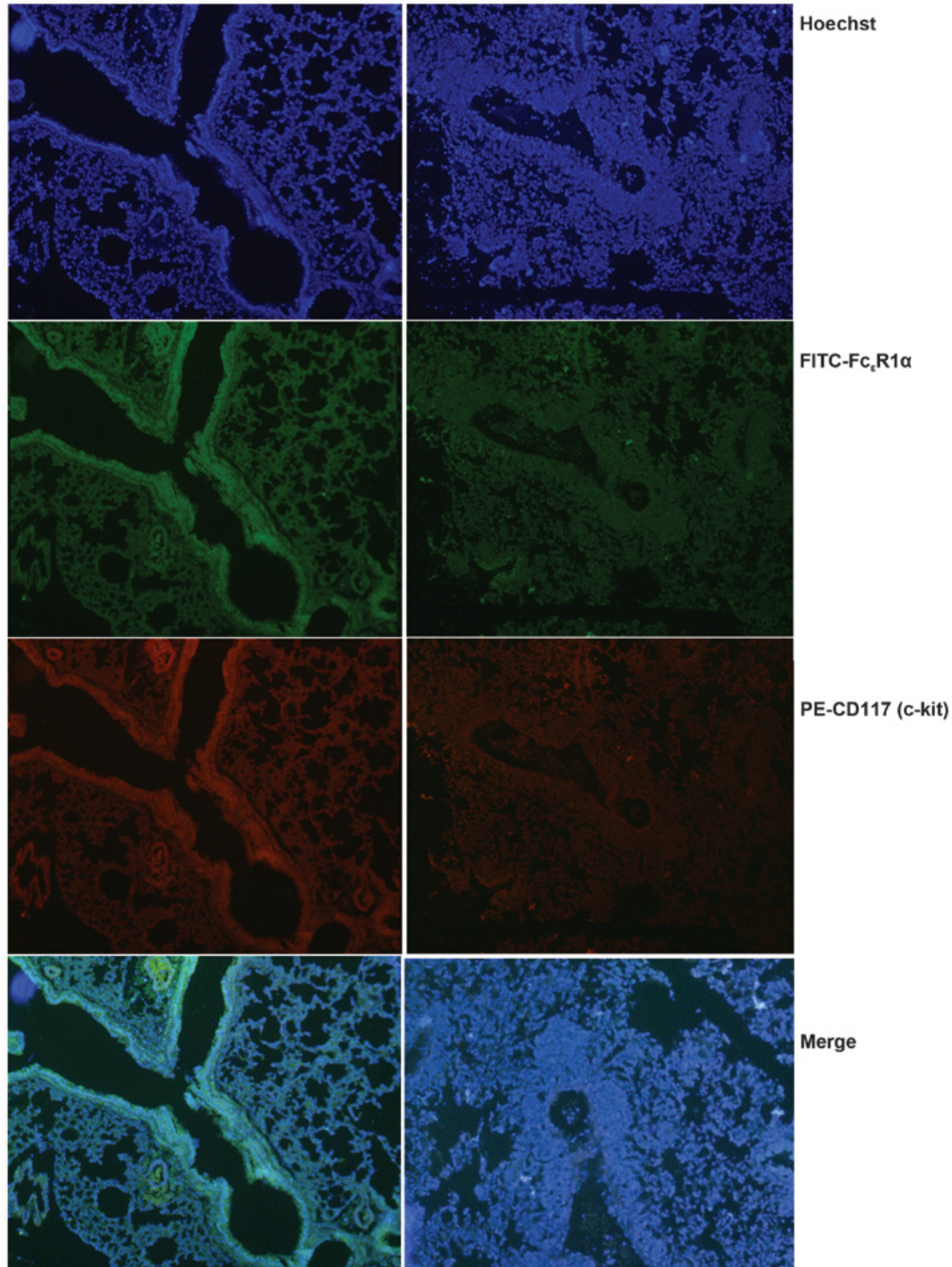

Control (x100)

Asthmatic mouse model (x100)

Figure 6. Increased FceR positive cells in inflammatory lung tissue. FITC-FceR1 $\alpha$ and PE-CD117 antibodies were used to detect the $\mathrm{Fc}_{\varepsilon} \mathrm{R}$ positive cells in inflammatory lung tissue by immunofluorescence staining, and the results were observed by fluorescence microscope. The result demonstrated that the positive staining was markedly increased in the lung tissue samples from asthmatic mice compared with the control. FITC, fluorescein isothiocyanate; $\mathrm{Fc}_{\varepsilon} \mathrm{R} 1 \alpha$, high-affinity immunoglobulin E receptor $1 \alpha$; PE, phycoerythrin; $\mathrm{CD}$, cluster of differentiation.

Association between the expression levels of ILC2 or Th9-associated factors in lung tissue and IgE in serum from asthmatic mice. IL-5 and IL-13, and IL-9 are characteristic cytokines produced by ILC2s and Th9 cells, respectively. The receptors of these cytokines were expressed in inflammatory lung tissue samples, which was indicative of a positive response to these two types of cell in the lung tissue. Correlation analysis indicated that the expression levels of IL-5R $\mathrm{R}_{\alpha}, \mathrm{IL}-13 \mathrm{R}_{\alpha 2}$ and IL-9 $\mathrm{R}_{\alpha}$ within the inflammatory lung tissue were associated with serum IgE level, and that there was significantly positive correlation between them in mouse models of asthma. In addition, the positive correlation was also demonstrated between the expression levels of ILC2-associated transcription factors or cytokine receptors and Th9 characteristic cytokines in the inflammatory lung tissue (Fig. 7). The results from the present study indicated that ILC2s and Th9 were in a state of polarization and they may promote each other in the inflammatory lung tissue.

\section{Discussion}

Since the identification of polarized $\mathrm{T}$ cell subsets, the type 2 immune response (Th2 mediated response) has increasingly been identified as a critical component in various human diseases. Defined by the particular cell types involved, adaptive and innate immune cells, and the soluble mediators that they release, type 2 immunity may exert protective and potentially harmful effects during various disease states, notably cancer, infection, autoimmunity, and tissue repair. An improved understanding of immune regulation in the context 

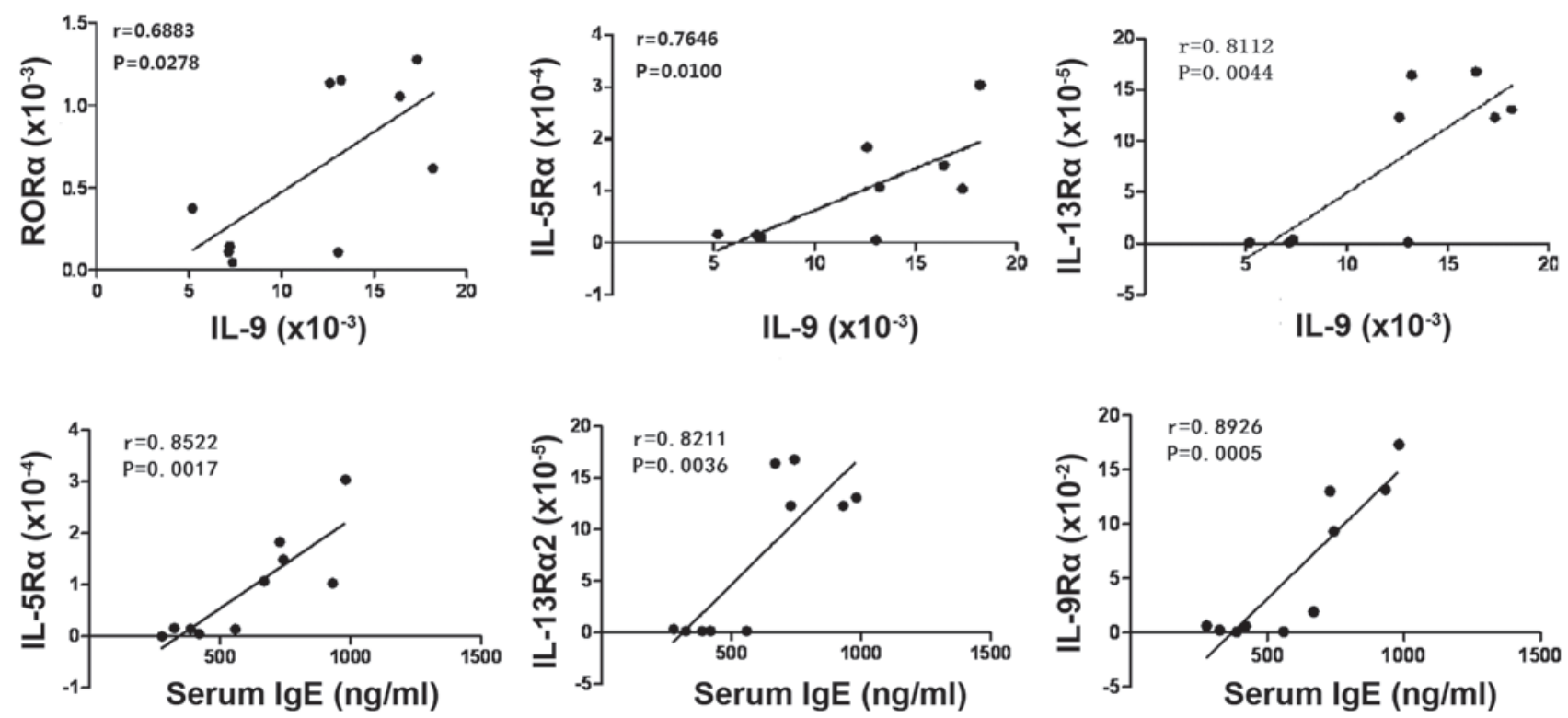

Figure 7. Positive correlation between the expression levels of ILC2s or Th9-associated factors in lung tissue samples and IgE in serum samples from asthmatic mice. There were significantly positive correlations between the expression levels of IL-5R $\alpha$, IL-13R $\alpha 2$ or IL-9R $\alpha$ in the inflammatory lung tissue and serum IgE level in asthma mice. In addition, the positive correlations were also found between the expression levels of ILC2s associated transcription factors or cytokine receptors and Th9 characteristic cytokines in the inflammatory lung tissue samples. ILC2s, innate lymphoid cells 2; Th9, T helper 9; IgE, immunoglobulin E; IL, interleukin; IL-5R $\alpha$, IL-5 receptor $\alpha$; IL-13R $\alpha 2$, IL-13 receptor $\alpha 2$; IL-9R $\alpha$, IL-9 receptor $\alpha$; ROR $\alpha$, RAR-related orphan receptor $\alpha$.

of various diseases is important in the development of novel therapeutic approaches, for example, the epithelium produces cytokines and its role in the development of inflammatory events requires further elucidation. Recent progress in the understanding the interaction between immune and inflammatory cell subsets and ILs aids in the development of novel ideas for immune intervention, particularly with regards to reciprocal regulation and counter balance between Th1, Th2, Th9, Th17 and T regulatory cells, as well as B-cell subsets. The process of developing allergic diseases is characterized by effector Th2 cells, which produce characteristic cytokines, and contribute to tissue inflammation, IgE production, eosinophilia, mucous production, and activation and cell death in the epithelium. They are emerging key factors in the pathogenesis of allergic inflammatory diseases, and they include ILC2s $(24,25)$. It has been demonstrated that Th9 cells and/or ILC2s are Th2 cell facilitators, and maintain Th2 cell polarization in certain immune inflammatory diseases (25-27).

ILC2s are IL-5 and IL-13-expressing nuocytes, the transcription factor ROR $\alpha$ is essential for the development and function of ILC2s and ST2 and IL-17RB are relatively specific receptors to ILC2s. Th9 cells are an T-helper cell subset that produces IL-9 and is also involved in type I hypersensitivity, including airway inflammation (28). Although its critical roles in asthma have attracted interest, the physiological regulatory mechanisms of Th9 cell differentiation and function are largely unknown. IL-9 influences numerous cell types, including T cells, B cells, mast cells, eosinophils, lung epithelial cells, and hematopoietic progenitors (29). Although type I hypersensitivity had been considered a Th2 cytokine (IL-4, IL-5, and IL-13)-mediated reaction, recent findings have shown that blocking IL-4 signaling had little effect on human asthma, and IL-9 is currently of interest as a potential novel therapeutic target of type I hypersensitivity (30). During the pathological process of pulmonary inflammation in asthma, IL-9 promotes the proliferation and differentiation of mast cells and increases production of IgE by $\mathrm{B}$ cells (6). It also promotes expression of mast cell proteases and upregulates the $\mathrm{Fc}_{\varepsilon} \mathrm{R}$ (7-10).

Asthma is one of the most common lifelong chronic diseases, it is a reversible airway obstruction that is characterized by constriction of airway smooth muscle, hyper secretion of mucus, edema and AHR, mucus secretion and thickening of the basement membrane underneath the airway epithelium. Th9 has recently been considered the most important mediators during the development of immune responses in the lung of asthma, and ILC2s have been described as a novel type of innate immunocyte with the ability to enhance $\operatorname{IgE}$ production. However, the interaction between ILC2s and Th9 cells in asthmatic mice pulmonary tissues has not been unambiguously characterized. The present study described the response state of lung tissue to Th9 cells and ILC2s in asthmatic mice by analyzing the associated receptors of these types of cell, and detected the association between the expression levels of the characteristic cytokine receptors for the two types of cells in lung tissue and $\operatorname{IgE}$ in sera samples from mouse models of asthma. Results from the present study demonstrated that the frequency of ILC2 and Th9 cells was significantly increased in the lung tissue of asthmatic mice $(\mathrm{P}=0.007$ and $\mathrm{P}=0.036$, respectively), in addition to the increased $\mathrm{mRNA}$ expression levels of ROR $\alpha$, ST2, PU.1 and IL-9. Immunofluorescence staining of lung tissue samples also demonstrated similar results. In addition, IL-5R $\alpha, \mathrm{IL}-13 \mathrm{R} \alpha 2$ and $\mathrm{Fc}_{\varepsilon} \mathrm{R}$ were also enhanced in pulmonary tissue from mouse models of asthma, and a positive association was observed between the expression levels of ILC2- or Th9-associated receptors, or cytokines in tissue samples and IgE in sera. It indicated that ILC2s and 
Th9 were in a state of polarization and that they may promote each other in the lung tissue of mouse models of asthma, and furthermore, the lung tissue exhibited a positive response to the two types of cell (indicated by the increased expression of cytokine receptors).

The present study investigated the changes in the numbers of ILC 2 and Th9 cells in peripheral blood samples, and this was compared with the frequency of the two classes of cells in the lung tissue samples from mouse models of asthma. It was observed that the number of ILC2 and Th9 cells was markedly increased in the lung tissue samples, but not in peripheral blood samples. Asthma is a local respiratory allergic inflammatory disease, and pulmonary or bronchial responses to environmental change are associated with the pathological process. The results from the present study suggested that ILC2s and Th9 cells may be important in the local tissue in asthma. In addition, the predominant expression of ILC2- and Th9-associated molecules emerged in lung tissue samples from asthmatic mice, which indicated a positive response to the two types of cells in inflammatory lung tissue. The present study also investigated the association between the expression levels of ILC2- or Th9-associated factors in lung tissue and $\mathrm{IgE}$ in serum from mouse models of asthma and the results indicated that the expression levels of IL-5R $\mathrm{R}_{\alpha}, \mathrm{IL}-13 \mathrm{R}_{\alpha 2}$ and IL-9 $R_{\alpha}$ within the inflammatory lung tissue were associated with serum IgE levels and there were significantly positive correlations between the two parameters in mouse models of asthma. The positive correlation was also demonstrated between the expression levels of ILC2-associated transcription factors or cytokine receptors and characteristic cytokines of Th9 cells in the inflammatory lung tissue. It indicated that ILC2s and Th9 cells were in a state of polarization and they may promote each other in the lung tissue of asthmatic mice.

MBP-1, IRF4 and PU.1 are key regulators of lymphoid, myeloid and dendritic cell differentiation, including the differentiation of mature B cells into antibody-secreting plasma cells, and Th9 cells to produce IL-9 (31). IL-9 increases the expression of mast cell surface $\operatorname{IgE~} \mathrm{Fc}_{\varepsilon} \mathrm{RIa}$, and promotes IL-5 to mediate the maturation of eosinophil precursors via the inhibition of eosinophil apoptosis (32). Furthermore, IL-9 generated by Th9 cells may promote the differentiation of ILC2s and secretion of IL-5, which further increases IgE production and eosinophil proliferation (33). The results of the present study demonstrated that these regulatory factors and Th9 or ILC2s characteristic cytokines, including MBP-1, IRF4, PU.1, IL-5, IL-9 and IL-13, were significantly increased in inflammatory lung tissue. Thus, the interaction between Th9 and ILC2s was evident, and the results suggested they may contribute to the IgE production involved in pathological process of asthma.

In conclusion, ILC2s and Th9 cells were polarized and may promote each other in the lung tissue of mouse models of asthma, furthermore, increased expression of associated receptors in the lung tissue demonstrated the positive response to the two types of cell. IgE has long been a therapeutic target for allergic disease, further understanding the interaction of ILC2s and Th9 cells in the development of asthma, and its effect on $\mathrm{IgE}$, will contribute to the elucidation of the pathogenesis of asthma and aid in the development of more effective prevention measures and therapeutic strategies.

\section{Acknowledgements}

The present study was supported by grants from the National Natural Science Foundation of China (grant nos. 31270947, 31170849 and 81370084), the Natural Science Foundation of Jiangsu Province (grant no. BK2011472) and the Postdoctoral Foundation of China (grant no. 2013T60508).

\section{References}

1. Guo HW, Yun CX, Hou GH, Du J, Huang X, Lu Y, Keller ET, Zhang J and Deng JG: Mangiferin attenuates Th1/Th2 cytokine imbalance in an ovalbumin-induced asthmatic mouse model. PLOS One 9: e100394, 2014.

2. Chen W, Sivaprasad U, Gibson AM, Cunningham CM, Bass SA, Kinker KG, Finkelman FD, Wills-Karp $M$ and Khurana Hershey GK: IL-13 receptor $\alpha 2$ contributes to development of experimental allergic asthma. J Allergy Clin Immunol 132: 951-958, 2013.

3. Farahani R, Sherkat R, Hakemi MG, Eskandari N and Yazdani R: Cytokines (interleukin-9, IL-17, IL-22, IL-25 and IL-33) and asthma. Adv Biomed Res 3: 127, 2014

4. Horka H, Staudt V, Klein M, Taube C, Reuter S, Dehzad N, Andersen JF, Kopecky J, Schild H, Kotsyfakis M, et al: The tick salivary protein sialostatin L inhibits the Th9-derived production of the asthma-promoting cytokine IL-9 and is effective in the prevention of experimental asthma. J Immunol 188: 2669-2676, 2012.

5. Besnard AG, Sabat R, Dumoutier L, Renauld JC, Willart M Lambrecht B, Teixeira MM, Charron S, Fick L, Erard F, et al: Dual Role of IL-22 in allergic airway inflammation and its cross-talk with IL-17A. Am J Respir Crit Care Med 183: 1153-1163, 2011.

6. Ma L, Xue HB, Guan XH, Shu CM, Zhang JH and Yu J: Possible pathogenic role of T helper type 9 cells and interleukin (IL)-9 in atopic dermatitis. Clin Exp Immunol 175: 25-31, 2014.

7. Pilette C: Pathophysiology of asthma: Data concerning regulation of IGE and Th2 responses in the lung. Bull Mem Acad R Med Belg 166: 280-287, 2011 (In French).

8. Chen Y, Thai P, Zhao YH, Ho YS, DeSouza MM and Wu R: Stimulation of airway mucin gene expression by interleukin (IL)-17 through IL-6 paracrine/autocrine loop. J Biol Chem 278: 17036-17043, 2003.

9. Gasch M, Goroll T, Bauer M, Hinz D, Schütze N, Polte T, Kesper D, Simon JC, Hackermüller J, Lehmann I and Herberth G: Generation of IL-8 and IL-9 producing CD4 ${ }^{+} \mathrm{T}$ cells is affected by Th17 polarizing conditions and AHR ligands. Mediators Inflamm: 182549, 2014

10. Kung TT, Luo B, Crawley Y, Garlisi CG, Devito K, Minnicozzi M, Egan RW, Kreutner W and Chapman RW: Effect of anti-mIL-9 antibody on the development of pulmonary inflammation and airway hyperresponsiveness in allergic mice. Am J Respir Cell Mol Biol 25: 600-605, 2001.

11. Spits H, Artis D, Colonna M, Diefenbach A, Di Santo JP, Eberl G, Koyasu S, Locksley RM, McKenzie AN, Mebius RE, et al: Innate lymphoid cells-a proposal for uniform nomenclature. Nat Rev Immunol 13: 145-149, 2013.

12. Lund S, Walford HH and Doherty TA: Type 2 innate lymphoid cells in allergic disease. Curr Immunol Rev 9: 214-221, 2013.

13. Fukuoka A, Futatsugi-Yumikura S, Takahashi S, Kazama H, Iyoda T, Yoshimoto T, Inaba K, Nakanishi K and Yonehara S: Identification of a novel type 2 innate immunocyte with the ability to enhance IgE production. Int Immunol 25: 373-382, 2013.

14. Gold MJ, Antignano F, Halim TY, Hirota JA, Blanchet MR, Zaph C, Takei F and McNagny KM: Group 2 innate lymphoid cells facilitate sensitization to local, but not systemic, TH2-inducing allergen exposures. J Allergy Clin Immunol 133: 1142-1148, 2014.

15. Wang SY, Yang M, Xu XP, Qiu GF, Ma J, Wang SJ, Huang XX and Xu HX: Intranasal delivery of T-bet modulates the profile of helper $\mathrm{T}$ cell immune responses in experimental asthma. J Investig Allergol Clin Immunol 18: 357-365, 2008.

16. He Z, Shotorban SS, Jiao Z, Su Z, Tong J, Liu Y, Shen P, Ma J, Gao J, Wang T, et al: HMGB1 promotes the differentiation of Th17 via up-regulating TLR2 and IL-23 of CD14+ monocytes from patients with rheumatoid arthritis. Scand J Immunol 76: 483-490, 2012. 
17. Wu Y, Yan Y, Su Z, Bie Q, Wu J, Wang S, Yu Y, Ding H, Lu P and $\mathrm{Xu} \mathrm{H}$ : Enhanced circulating ILC2s accompany by upregulated MDSCs in patients with asthma. Int J Clin Exp Pathol 8: 35683579,2015

18. Erpenbeck VJ, Hohlfeld JM, Discher M, Krentel H, Hagenberg A, Braun A and Krug N: Increased expression of interleukin-9 messenger RNA after segmental allergen challenge in allergic asthmatics. Chest 123: 370S, 2003.

19. Shimbara A, Christodoulopoulos P, Soussi-Gounni A, Olivenstein R, Nakamura Y, Levitt RC, Nicolaides NC, Holroyd KJ, Tsicopoulos A, Lafitte JJ, et al: IL-9 and its receptor in allergic and nonallergic lung disease: Increased expression in asthma. J Allergy Clin Immunol 105: 108-115, 2000.

20. Dardalhon V, Awasthi A, Kwon H, Galileos G, Gao W, Sobel RA, Mitsdoerffer M, Strom TB, Elyaman W, Ho IC, et al: IL-4 inhibits TGF-beta-induced Foxp3+ T cells and, together with TGF-beta, generates IL-9+ IL-10+ Foxp3(-) effector T cells. Nat Immunol 9: $1347-1355,2008$.

21. Veldhoen M, Uyttenhove C, van Snick J, Helmby $H$, Westendorf A, Buer J, Martin B, Wilhelm C and Stockinger B Transforming growth factor-beta 'reprograms' the differentiation of $\mathrm{T}$ helper 2 cells and promotes an interleukin 9-producing subset. Nat Immunol 9: 1341-1346, 2008

22. Chang HC, Sehra S, Goswami R, Yao W, Yu Q, Stritesky GL, Jabeen R, McKinley C, Ahyi AN, Han L, et al: The transcription factor PU.1 is required for the development of IL-9-producing T cells and allergic inflammation. Nat Immunol 11: 527-534, 2010.

23. Kaplan MH: Th9 cells: differentiation and disease. Immunol Rev 252: 104-115, 2013.

24. Eiwegger T and Akdis CA: IL-33 links tissue cells, dendritic cells and Th2 cell development in a mouse model of asthma. Eur J Immunol 41: 1535-1538, 2011.
25. Bie Q, Zhang P, Su Z, Zheng D, Ying X, Wu Y, Yang H, Chen D, Wang $\mathrm{S}$ and $\mathrm{Xu} \mathrm{H}$ : Polarization of ILC2s in peripheral blood might contribute to immunosuppressive microenvironment in patients with gastric cancer. J Immunol Res: 923135, 2014.

26. Fahy JV and Locksley RM: The airway epithelium as a regulator of Th2 responses in asthma. Am J Respir Crit Care Med 184: 390-392, 2011.

27. Juncadella IJ, Kadl A, Sharma AK, Shim YM, HochreiterHufford A, Borish L and Ravichandran KS: Apoptotic cell clearance by bronchial epithelial cells critically influences airway inflammation. Nature 493: 547-551, 2013.

28. Mikami N, Miyagi Y, Sueda K, Takatsuji M, Fukada S, Yamamoto $\mathrm{H}$ and Tsujikawa $\mathrm{K}$ : Calcitonin gene-related peptide and cyclic adenosine 5'-monophosphate/protein kinase A pathway promote IL-9 production in Th9 differentiation process. J Immunol 190: 4046-4055, 2013.

29. Temann UA, Ray P and Flavell RA: Pulmonary overexpression of IL-9 induces Th2 cytokine expression, leading to immunepathology. J Clin Invest 109: 29-39, 2002.

30. Corren J: Cytokine inhibition in severe asthma: Current knowledge and future directions. Curr Opin Pulm Med 17: 29-33, 2011.

31. O'Flaherty BM, Soni T, Wakeman BS and Speck SH: The murine gammaherpesvirus immediate-early Rta synergizes with IRF4, targeting expression of the viral M1 superantigen to plasma cells. PLoS Pathog 10: e1004302, 2014.

32. Holgate ST: New strategies with anti-IgE in allergic diseases. World Allergy Organ J 7: 17, 2014.

33. Turner JE, Morrison PJ, Wilhelm C, Wilson M, Ahlfors $\mathrm{H}$, Renauld JC, Panzer U, Helmby $\mathrm{H}$ and Stockinger B: IL-9-mediated survival of type 2 innate lymphoid cells promotes damage control in helminth-induced lung inflammation. J Exp Med 210: 2951-2965, 2013. 